\title{
Estimation of protein rumen degradability by SDS-PAGE
}

\author{
GF Greppi 1, R Nola 2, S lametti 3, S Pagani 3, G Enne 4 \\ ${ }^{1}$ Facoltà di medica veterinaria, Dip Sc Anat, Fis Prod Anim, Viale delle piaggere 2, 56100 Pisa \\ 2 Ist Zoot Gen, Milan; \\ 3 Dip Sc Mol Agr Alim, Milan; \\ 4 Ist L Spallanzani, Milan, Italy
}

The nylon-bag technique allows in vivo analysis of rumen degradability of food proteins consisting of heterogeneous subfractions varying in aminoacid composition and structure and with different rumen degradability (Nocek, 1988). The aim of this study was to investigate the possibility of evaluating rumen degradability using electrophoretic techniques in order to get separation and molecular characterization of protein fractions.

Materials and methods. Residues of bovine rumen degradation of a group of feeds (corn gluten meal, cotton cake, linseed meal, sunflower seed) were defatted and the protein fraction was quantified

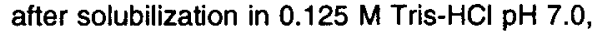
$2 \mathrm{mM}$ EDTA, 2\% (w/v) SDS, 1,5\% (v/v) $\beta$-mercaptoethanol. Samples containing $10 \mu \mathrm{g}$ nitrogen were electrophoresed according to Laemmli (1970). Fractional protein degradation was monitored by densitometric scanning of Coomassieblue-stained bands with a Kem-Antec camera and was refined by Cream 4.0 software.

Results. Table I reports the nitrogen degradability of examined feeds after 8 and $16 \mathrm{~h}$ rumen incubation. For each feed we observed a characteristic pattern of breakdown of the major protein components extracted with a wide range of susceptibilities to degradation. Data show in table II indicate that sunflower protein fractions isolated were characterized by higher ruminal degradability probably owing to their globulin nature, evidencing a very different range of degradability compared with total nitrogen. On the contrary, corn gluten meal showed a reduced ruminal degradability of both the total nitrogen and the protein fractions, probably due to the presence of hydrophobic zein fractions. Amino-acid composition of the major protein fractions is underway.

Work supported by RAISA grant 'Basi fisiologiche e fisiopatologiche dei processi produttivi', to GFG.

Nocek JE (1988) J Dairy Sci 71, 2051-2069

Laemmli UK (1970) Nature (Lond) 227, 680-685
Table I. Percentage disappearance of nitrogen from nylon bags incubated in the rumen.

\begin{tabular}{lrr}
\hline & $8 h$ & $16 h$ \\
\hline Corn gluten meal & 9.0 & 39.6 \\
Cotton cake & 29.8 & 43.5 \\
Linseed meal & 49.5 & 69.8 \\
Sunflower seed & 36.0 & 55.1 \\
\hline
\end{tabular}

Table II. Kinetics of rumen degradability of various feeds.

\begin{tabular}{ccrr}
\hline \multicolumn{4}{c}{ Relative \% of the protein fractions } \\
$M_{r}(k D a)$ & \multicolumn{3}{c}{ After } \\
& Before & $8 h$ & $16 h$ \\
& & & \\
& & & \\
Corn gluten meal & & & \\
43 & 100 & 50 & 24 \\
27 & 100 & 100 & 68 \\
22 & 100 & 100 & 72 \\
Cotton cake & & & \\
50 & 100 & 44 & 36 \\
44 & 100 & 49 & 64 \\
33 & 100 & 68 & 94 \\
20 & 100 & 100 & 100 \\
14 & 100 & 87 & 70 \\
Linseed meal & & & \\
35 & 100 & 100 & 82 \\
30 & 100 & 21 & 21 \\
23 & 100 & 78 & 79 \\
Sunflower seed & & & \\
50 & 100 & 23 & 13 \\
40 & 100 & 8 & 4 \\
34 & 100 & 7 & 7 \\
21 & 100 & 64 & 7 \\
18 & 100 & 24 & 9 \\
& & & \\
\hline & & &
\end{tabular}

Protein fractions were analysed by SDS-PAGE and the major protein bands were characterized before and after rumen infusion. 